Bahçe Bitkileri / Horticulture

DOI: $10.21597 / j i s t .753265$

Araştırma Makalesi / Research Article

Geliş tarihi / Received: 15-06-2020

Kabul tarihi / Accepted: 10-10-2020

Uzun ve Siirt Antepfıstığı Çeşitlerinde Hasat Öncesi Ethephon Uygulamasının Hasat Mekanizasyonuna Etkisi Ertuğrul İLIKÇĊOĞLU ${ }^{1}$, Halit Seyfettin ATLI ${ }^{2 *}$, Ferit ÇELIKK ${ }^{3}$

ÖZET: Bu çalışma bitkiler üzerinde olgunlaştırıcı etkisi bulunan ethephon isimli hormonun antepfıstığı (Pistacia vera L.) makinalı hasat üzerine olan etkisini incelemek amacıyla 2018 yılında Gaziantep’te yürütülmüştür. Çalışmada 40 yaşındaki Uzun ve Siirt antepfıstığı çeşidi ağaçları kullanılmıştır. Dört farklı ethephon dozu $(0, \quad 1000,3$ 000, 5 000 ppm) uygulanmıştır. Hormon dozları iki farklı hasat döneminden (boz, ben) 15 gün önce uygulanmıştır. Hasat omuzdan askılı kancalı dal sarsıcı makine ile yapılmıştır. Ayrıca ekonomik analiz yapmak amacıyla el ile hasat gerçekleştirilmiştir. Çalışmada fenolojik gözlem, salkım dökülme oranı, meyve kopma kuvveti, meyvelerin çeltikten kopma oranı, karagöz dökülme durumu, yaprak dökümü belirlenmiştir. Ayrıca meyveler üzerinde çıtlama oranı, çıtlama aralı̆̆ı, dış kabuk renklenmesi, iç rengi, dış kabuk ayrılması, dış kabuk yarılması, dış kabuklu 100 dane ağırlığı, kavlak 100 dane ağırlığı, kuru kırmızı kabuklu 100 dane ağırlığı, kuru kavlak 100 dane ağırlığı, iç 100 dane ağırlığı, randıman özellikleri incelenmiştir. Ayrıca geleneksel yöntem olan elle hasat ile makinalı hasat karşılaştırılmıştır. Çalışma sonunda uygulanan hormon dozunun salkımın daldan kopması ve meyvenin çeltikten ayrılması üzerine olumlu etkisi olduğu görülmüş olup yaprak dökümüne bir etkisi tespit edilmemiştir. Salkımın daldan kopması Uzun çeşidinin boz ve ben hasat dönemlerinde en fazla 5000 ppm dozunda görülürken, Siirt çeşidinin boz hasat döneminde 3000 ppm, ben hasat döneminde ise 5000 ppm dozunda görülmüştür. Danelerin salkımdan kopma durumunda da aynı dozlar ön plana çıkmıştır. Hasat süresi bakımından makinalı hasat çok daha hızlı sonuç vermiştir.

Anahtar Kelimeler: Antepfistığı, dal sarsıc1, ethephon, mekanik hasat, hormon

\title{
Effect of Pre-Harvest Ethephon Application on Harvest Mechanization of Uzun and Siirt Pistachio Varieties
}

ABSTRACT: This thesis was conducted in Gaziantep in 2018 to investigate the effects of pre-harvest ethephon hormone treatments with ripening effects on plants on harvest mechanization of different pistachio (Pistacia vera $\mathrm{L}$.) varieties. Pistachio tree of Uzun and Siirt pistachio varieties (at the age of 40) were used in experiments. Four different ethephon doses $(0,1000,3000,5000 \mathrm{ppm})$ were applied 15 days ahead of two different harvest periods (light, dark). Harvest was performed with a shoulder-type hooked branch shaker. Manual harvest was also performed to make economic analysis. Phenological observation, cluster abscission rate, fruit breaking resistance, endocarp removal force from the seed, flower bud abscission and leaf abscission rates were determined. Also for fruits, split ratios, split space, endocarp colouring, seed colour, endocarp separation, endocarp splitting, 100 endocarped fruit weight, 100 seed weight, 100 red seed coated weight, 100 dry roasted seed weight and 100 seed weight and seed yield were determined. Manual and machine harvests were compared. Applied hormone doses had positive effects on cluster breaking force from the branch and endocarp removal force from the seed, but did not have any significant effects on leaf abscission. The greatest cluster breaking force at both harvest periods was observed in $5000 \mathrm{ppm}$ treatments of Uzun variety and in $3000 \mathrm{ppm}$ treatments in light harvest period and $5000 \mathrm{ppm}$ treatments in dark harvest period of Siirt cultivar. The doses were also prominent for fruit breaking from the clusters. Machine harvest yielded quite fast outcomes as compared to manual harvest.

Keywords: Pistachio, branch shaker, ethephon, mechanical harvesting, hormone

${ }^{1}$ Ertuğrul İLİKÇİOĞLU (Orcid ID: 0000-0002-5818-045X), Antepfistığı Araştırma Enstitüsü Müdürlüğü, Gaziantep, Türkiye

${ }^{2}$ Halit Seyfettin ATLI (Orcid ID: 0000-0001-9485-0898), Siirt Üniversitesi, Ziraat Fakültesi, Bahçe Bitkileri Bölümü, Siirt, Türkiye

${ }^{3}$ Ferit ÇELIK (Orcid ID: 0000-0001-9089-2468), 100. Y1l Üniversitesi, Ziraat Fakültesi, Bahçe Bitkileri Bölümü, Van, Türkiye

*Sorumlu Yazar/Corresponding Author: Halit Seyfettin ATLI, e-mail: seyfettinatli@siirt.edu.tr

Bu çalışma Ertuğrul İLIKÇi̇̇ĞLU'nun Yüksek Lisans Tezinden üretilmiştir. 


\section{GİRiş}

Pistacia türleri dünyada kuzey ve güney yarım kürelerinin $30-45^{\circ}$ paralellerinin uygun mikroklimalarında yetişebilmektedir (Tekin ve ark., 1995). Antepfıstığı, ilk olarak Etiler zamanında Anadolu' da kültüre alınmış ve kral sofralarına kadar girmiştir. Anacardiaceae familyasına giren Pistacia cinsinin meyve ağacı ve süs bitkisi olarak değer kazanan 11 türü vardır (Özbek, 1978). Ayfer (1959)'e göre antepfıstığının iki gen merkezi bulunmaktadır: Orta Asya Gen Merkezi; Hindistan'ın kuzeyi, Afganistan, Tacikistan ve Pakistan diğeri ise Yakın Doğu Gen Merkezi; Anadolu, Kafkasya, İran ve Türkmenistan'dır. Ülkemiz de bu gen merkezinde olup, dünya antepfıstığı üretiminde söz sahibidir.

Antepfistığı değişik türdeki topraklara adapte olabilmekle birlikte, derin, yeteri kadar geçirgen, kumlu-tınlı ve yüksek oranda kireç içeren topraklarda daha iyi bir şekilde gelişmektedir (Joley, 1973). Her bakımdan kanaatkâr bir bitki olan antepfıstığı yoksul koşullara ve kurağa dayanıklıdır (Spiegel, 1977). Kayalık, taşlık, bitki besin elementlerince yoksul, sı ̆̆ ve kireçli topraklarda da antepfistı̆̆ yetiştiriciliği ekonomik olabilmektedir (Ayfer ve ark., 1986).

Ülkemizde Antepfistığı yetiştiriciliği Güney Doğu Anadolu Bölgesi başta olmak üzere Ege bölgesinin iç kesimlerinde, Akdeniz bölgesinde Torosların güney yamaçlarında, Orta Anadolu ve Doğu Anadolu'nun bazı bölgelerinde, yazları sıcak ve kurak, kışları nispeten soğuk geçen alanlarda yapılmaktadır (Arpacı ve ark., 1999; Ak ve ark., 1999).

Son 10 yıllık antepfıstığı üretim istatistiklerine göre İran 453339 ton yı1 ${ }^{-1}$ üretimi ile ilk sırada yer alırken bunu 220404 ton yıl ${ }^{-1}$ ile ABD izlemektedir. Türkiye 115251 ton yıllık ortalama ile üçüncü, Çin ise 71126 ton üretim ile dördüncü sırada yer almaktadır (Anonim, 2018a).

Antepfistığ üreten ülkeler arasında son 10 yıllık ihracat değerlerine göre Türkiye'nin 22810 ton ile beşinci sırada bulunmakta, İran 120546 ton ile birinci, Amerika Birleşik Devletleri 109480 ton ile ikinci, Çin 57528 ton ile üçüncü sırada yer almaktadır (Anonim, 2018b). Antepfistığının iç ve dış pazarlarda iyi gelir getirmesi sebebiyle son yıllarda ABD ve İran'daki antepfıstığı bahçe tesislerine benzer tesisler ülkemizde de kurmaktadır. Modern teknikler ve sulama sistemleri kullanılmaktadır.

Ülkemizdeki bu geleneksel yetiştiriciliğin yanında, uygun ekolojide, iyi çeşitler ve uygun tozlayıcılar kullanılarak ve kuru şartlarda $170 \mathrm{~kg} \mathrm{da}^{-1}$, sulu şartlarda $320 \mathrm{~kg} \mathrm{da}^{-1}$ ürün alınabileceği saptanmıştır (Atlı ve ark., 2002; Atlı ve ark., 2008).

Ülkemizde yaygın olarak tesis edilen antepfıstığı bahçelerinde hasat işlemi geleneksel yöntem olan antepfıstığı cumbalarının (salkım) el ile tek tek kırılarak daldan ayrılması şeklinde yapılmaktadır. Bu şekilde yapılan hasat ise işgücünü artırmakta, hasat süresini uzatmaktadır. Aynı zamanda el ile hasat yapılırken bir sonraki yılın meyvelerini oluşturacak olan karagözlerin (meyve gözü) zarar görmesi sonucunda ertesi yıl alınacak ürün miktarı önemli ölçüde azalabilmektedir (Atlı ve ark., 1999).

Dünyada sert kabuklu meyvelerin hasadı gelişmiş ülkelerde önemli ölçüde makineleşmiştir. Özellikle antepfıstığı üretiminde ortalama 220000 tonluk üretimi ile önemli bir paya sahip olan Amerika Birleşik Devletleri'nde antepfıstığı yetiştiriciliği yapılan bahçelerin tamamında hasat işlemi makineleşmiştir. Bunun sonucunda hasat maliyeti ve süresini önemli ölçüde düşürerek ekonomik anlamda dünya pazarında önemli bir yer edinmiştir. ABD'de antepfistığının çeşitli sorunları üzerine sürdürülen bilimsel araştırmalar bu ülkede verimin ve kalitenin çok yükselmesine yol açmıştır (Uzun, 1998).

Son yıllarda meyvecilik alanlarının genişlemesi ve büyük ticari bahçelerin kurulmasına paralel olarak özellikle meyve suyu endüstrisinin ilerlemesiyle, mekanik hasada duyulan ilgi artmaktadır. Çünkü kurulan geniş ticari meyve bahçelerinde elle hasat yapılması, elde edilecek ürünün maliyetini oldukça artırmaktadır (Pırlak ve Güleryüz, 2000). Bu nedenle, meyvelerin mekanik olarak hasat 
edilmesi, birçok ürünün daha kârlı olabilmesi için anahtar bir faktör olarak düşünülmektedir (Sergio ve ark., 2008). Gaziantep'te yapılan bir çalışmada da antepfıstığı üretiminde iş gücünün büyük bir bölümünün budamanın ardından hasat işlemlerinde kullanıldığı saptanmıştır (Eldoğan ve Şahin, 2015).

Elle meyve hasadı meyveden meyveye değişmekle birlikte, ortalama olarak 450-2 000 İGH ha ${ }^{-1}$ (İnsan İş Gücü-Saat hektar ${ }^{-1}$ ) gerektirmektedir. Bu rakam üretim için toplam çalışma zamanının \% 4080'ini, toplam üretim maliyetinin \% 30-60'ını oluşturmaktadır. Meyve ağaçlarının hasadı tahıla göre iş gücü bakımından 100-250 kat, üretim masrafı bakımından ise yaklaşık 40 kat fazla olmaktadır (Tuncer ve Özgüven, 1989). Bu nedenlerle, birçok meyve türünün mekanik yolla hasat edilmesi; gereksinim duyulan yüksek iş gücü ile hasat masraflarının azaltılabilmesi ve ürün maliyetinin belirlenmesi ve düşürülmesi için önemli olmaktadır (Tous ve ark., 1994; Beyhan ve Yıldız, 1996).

Polat ve ark. (2007) Antepfıstığının mekanik hasadı üzerine yapmış oldukları çalışmalarında atalet kuvvet tipli bir sarsıcı ile antepfıstığının değişik genlik (40, 50 ve $60 \mathrm{~mm})$ ve değişik frekanslarda (10, 15 ve $20 \mathrm{~Hz}$ ) maksimum hasat etkinliğini belirlemeye çalışmışlardır. Sarsma işleminde sabit bir sarsma süresi (10 sn) kullanılmıştır. Ayrıca bu yöntemi elle hasat yöntemi ile karşılaştırmışlardır. Sonuçta en yüksek hasat oranını (\%100) $60 \mathrm{~mm}$ genlik ve $20 \mathrm{~Hz}$ frekansta bulmuş olmalarına rağmen $50 \mathrm{~mm}$ genlik ve $20 \mathrm{~Hz}$ frekans ile yapılan hasat işleminde makinanın daha iyi kontrol edilebildiğini ve bu nedenle bu değerlerin kullanılmasını önermektedirler. Kırmızı çeşidi antepfıstığında en uygun hasat döneminin yapmış oldukları ölçümlere göre Eylül ayı başlarında olduğunu belirtmektedirler.

Atlı ve ark. (1999) yaptıkları çalışmada; bazı standart antepfıstığı çeşitlerinin hasat zamanlarının saptamış, hasat zamanlarındaki toplam sıcaklık isteklerinin tespit etmiş ve Siirt, Ohadi, Uzun çeşitlerinin makineli hasada uygunluğunu belirlemişlerdir.

Ethephon ; Avrupa kıtasında ticari olarak yoğun bir şekilde kullanıldıktan sonra Amerika'ya girmiş, ancak bu kıtadaki gerek yetiştirme tekniklerinin farklılığı gerekse iklim koşullarının farklılığı ethephon kullanımını sınırlandırmıştır (Simmons ve ark., 1988). Ethephon hormonunun bitkilerdeki kullanımında ortaya çıkan en önemli özelliği olgunlaşmayı hızlandırmasıdır.

Antepfistığı gibi sert kabuklu bir meyve türü olan ceviz üzerinde gerçekleştirilen bir çalışmada 2009 ve 2010 yıllarında yapılan ölçümlerde ethephon uygulamasının üç farklı ceviz çeşidinde kopma kuvveti üzerinde olumlu bir etki yaptığı bildirilmiştir (Yalçın ve ark., 2012).

Çalışmamızda da bitki gelişme düzenleyici hormonlardan birisi olan ethephonun farklı dozları kullanılarak antepfıstığı meyvelerinin çeltikten, çeltiklerin ise daldan ayrılma durumları incelenmiştir. Elde edilen veriler geleneksel yöntemle karşılaştırılarak ekonomik analiz yapılmıştır.

\section{MATERYAL VE YÖNTEM}

\section{Materyal}

Çalışmada materyal olarak; sulanmayan parseldeki, 8x8 m sıra arası ve sıra üzeri mesafelerde dikilmiş olan 40 yaşındaki Uzun ve Siirt antepfıstığı çeşidi ağaçları kullanılmıştır.

Uzun çeşidi, ülkemizde yetiştiriciliği yapılan en yaygın antepfıstığı çeşididir. Meyveleri orta irilikte olup, lezzeti ve aromasıyla ön plandadır. Meyveleri çerezlik olarak tüketilebildiği gibi erken hasat (boz kırma) edilerek yeşil iç olarak tatlı ve çikolata gibi gıda sanayisinde yoğun olarak kullanılmaktadır. Siirt çeşidi, son yıllarda ülkemizde yetiştiriciliği yaygınlaşmaya başlayan yüksek kaliteli standart antepfıstığı çeşitlerimizden birisidir. Periyodisite eğilimi az olup, hasat işlemi ise Eylül ayı sonundadır. İç meyve renginin sarı olduğundan genellikle çerezlik olarak tüketilmektedir (Tekin ve ark., 2001).

Uygulamalarda kullanılan Ethephon, meyvenin özellikle sapın dala bağlı olduğu kısımda yaşlanmayı hızlandırarak kopmayı kolaylaştırmaktadır. Aprol (ethephon, $480 \mathrm{~g} \mathrm{~L}^{-1}$ ) ve yapıştırıcı olarak 
Tween-20 kullanılmıştır. Çalışmada kullanılan dal sarsıcı hasat makinası omuzdan asılır tipte, 12500 devirde 3328 vuruş yapabilmekte ve motor gücü $2.20 \mathrm{~kW}$ (3.00 BG) dir.

\section{Yöntem}

Çalışma tesadüf blokları deneme desenine göre 3 tekerrürlü olarak kurulmuş, her tekerrürde 1 ağaç kullanılmıştır. Çalışmada 4 farklı ethephon dozu (0, 1 000, 3 000, 5000 ppm) uygulanmıştır. Kontrol grubuna ise herhangi bir uygulama yapılmamıştır (Yalçın ve ark., 2012).

\section{Hormon Uygulama Dönemleri}

Antepfistığı yetiştiriciliğinde iki farklı olgunluk döneminde (boz kırma, ben kırma) hasat yapılmaktadır. Bu hasat dönemlerinden 15'er gün önce hormon dozları ağaçlara uygulanmıştır.

Boz hasat hormon uygulaması; Uzun çeşidi için 18 Temmuzda, Siirt çeşidi için 29 Temmuzda gerçekleştirilmiştir. Normal (ben) hasat hormon uygulaması; Uzun çeşidi için 11 Ağustosta, Siirt çeşidi için 15 Eylülde yapılmıştır.

Hazırlanan çözelti gece hava sıcaklığı $27 \mathrm{C}^{0}$ 'nin altına düştüğü saatte motorlu pülverizatörle Yalçın ve ark. (2012)'ye göre tüm ağacı tamamen ıslatacak şekilde yapılmıştır.

\section{Hasat}

Normal hasat ve boz hasat hormon uygulamalarından 15 gün sonra omuzdan askılı dal sarsıcı hasat makinası ve elle yapılmıştır.

Çiçeklenme, hasat zamanları ve yaprak döküm tarihleri gözlemlenerek, çiçeklenmeden hasada kadar geçen toplam gün sayısı ve sıcaklık toplamı Atlı ve ark. (1999)'a göre hesaplanmıştır.

\section{Dökülen Salkım Sayısı}

Hasattan sonra ağaçta kalan çeltikler (salkım iskeletleri) ve dökülen salkımlar sayılmıştır. Ayrıca ben hasat döneminde ağaçta kalan çeltikler elle koparılmayıp uygulanan hormon dozlarının çeltik dökümüne etkisini gözlemlemek amacıyla Ocak ayında çeltik sayımı yapılmıştır.

\section{Hasat Başarısı/Etkinlik (\%) ve Hasat Süresi (sn.)}

Çalışmada incelenen hasat kriterleri için hasat etkinliği ağaç başına ayrı ayrı aşağıdaki şekilde Polat ve ark., (2007)'ye göre belirlenmiş, hasat süresi kronometre ile tespit edilmiştir.

$\mathrm{HY}=\mathrm{K} 1 /(\mathrm{K} 1+\mathrm{K} 2) * 100$

HY: Hasat Yüzdesi/Etkinliği,

$\mathrm{K} 1$ : Hasat edilebilen ürün $\left(\mathrm{kg}\right.$ ağaç $\left.{ }^{-1}\right)$,

K2: Hasattan sonra ağaçta kalan ürün $\left(\mathrm{kg}_{\mathrm{ağaç}}{ }^{-1}\right)$

\section{Meyve Kopma Kuvveti (kgF)}

Ölçüler tepe noktasını belirleyebilme özelliği olan 10 Newton (1kgF) kapasiteli analog bir dinamometre ile $\mathrm{kgF}$ cinsinden yapılmıştır. Ölçüm ağacın 4 yönünden olmak üzere 40 meyvede ölçüm yapılarak meyve kopma kuvvetleri tespit edilmiştir. Meyvenin sap kısmına çift uçlu kanca geçirilerek çekilmiş ve koptuğu andaki gösterge rakamı okunmuştur.

\section{Meyvelerin Çeltikten Kopma Durumu}

Meyvelerin çeltikten ayrılma durumu hasat sonrası ağaçtan yere düşen 25 çeltik gözlemlenerek salkım üzerinde kalan ve dökülen meyveler her ağaç için ayrı sayılmıştır.

\section{Karagöz Sayımı}

Uygulama yapılan ağaçlarda üzerinde karagöz bulunan beş yaşındaki birer dalda hormon uygulamasından önce ve hasattan hemen sonra ve Ocak ayında karagöz sayımı Tekin (1991)'e göre yapılarak uygulanan hormon dozlarının karagöz dökümüne etkisi belirlenmiştir. 


\section{Yaprak Dökümü}

Uygulanan dozların yaprak dökümüne etkisi hasat sonrasında ağaçta kalan ve dökülen yaprak oranı gözlemlenerek belirlenmiştir (Tahtacı ve ark., 2007).

\section{Pomolojik özellikler}

Uygulanan farklı dozdaki hormonun meyve kalite değerlerine olumlu-olumsuz etkisi belirlenmiştir. Meyveler üzerinde aşağıdaki özellikler incelenmiştir.

Tekerrürleri temsil edecek şekilde her ağaçtan hasat edilen meyve karışımlarından birer kilogramlık örnekler Arpacı ve ark. (1995)'e göre alınmış ve alınan örneklerden taze olarak 100 adedinde dış kabuk renklenmesi, dış kabuk ayrılması, dış kabuk yarılması, yaş dış kabuklu 100 dane ağırlı̆̆ı, taze kavlak 100 dane ağırlığg özellikleri belirlenmiştir.

Kalan örnekler ve 100 adet kavlak meyve oda koşullarında kurutulmuştur. Kurutulan kabuklu örneklerden 100 adet içli meyve sayılarak tartılmış ve yüz dane ağırlığı, çıtlama oranı, çıtlama aralı̆̆ (dar, orta, geniş), iç rengi (yeşil, sarımsı yeşil, gül) ve kuru iç meyve ağırlığı belirlenmiştir.

Daha önce kavlatılarak kurutulan örnekler tartılarak kuru kavlak 100 dane ağırlığı bulunmuştur. Randıman ise kuru kabuklu 100 dane ağırlığı ile bu meyvelerin içlerinin ağırlığının oranı hesaplanarak Arpacı ve ark. (1995)'e göre belirlenmiştir.

\section{Geleneksel Yöntemle Hasat}

Geleneksel hasat el ile cumbaların tek tek kırılması şeklinde yapılmıştır (Atlı ve ark., 1999).

\section{Verilerin Değerlendirilmesi}

Elde edilen veriler JMP İstatistik Paket Programı ile analiz edilmiş, çoklu karşılaştırmalar LSD testi ile değerlendirilmiştir $(\mathrm{p}<0.05)$.

\section{BULGULAR VE TARTIŞMA}

\section{Fenolojik Gözlemler}

Uzun çeşidinde tam çiçeklenme 11 Nisan 2018'de, boz hasat olgunluğu 3 Ağustos 2018 tarihinde gerçekleşmiştir. Tam çiçeklenmeden boz hasat tarihine kadar toplam 114 gün geçmiş olup, bu süre içerisinde sıcaklık toplamı 2304 saat olarak gerçekleşmiştir. Ben olum ise 27 Ağustos 2018 tarihinde gerçekleşmiştir. Tam çiçeklenmeden ben hasat tarihine kadar toplam 138 gün geçmiş olup, bu süre içerisinde sıcaklık toplamı 3036 saat olmuştur (Çizelge 1).

Siirt çeşidinde tam çiçeklenme 18 Nisan 2018'de, boz hasat olgunluğu 13 Ağustos 2018 tarihinde gerçekleşmiştir. Tam çiçeklenmeden boz hasat tarihine kadar toplam 117 gün geçmiş olup, bu süre içerisinde sıcaklık toplamı 2288 saat olmuştur. Ben olum ise 1 Ekim 2018 tarihinde gerçekleşmiştir. Tam çiçeklenmeden ben hasat tarihine kadar toplam 166 gün geçmiş olup, bu süre içerisinde sıcaklık toplamı 3680 saat olmuştur (Çizelge 1). Daha önce bu konuda çalışma yapan Atlı ve ark. (1999)'a yakın değerler elde edilmiştir.

Çizelge 1. Uzun ve Siirt çeşitlerinin fonolojik gözlem değerleri

\begin{tabular}{|c|c|c|c|c|c|c|c|c|c|c|}
\hline \multirow[t]{2}{*}{ Çeşitler } & \multirow[t]{2}{*}{$\begin{array}{c}\text { Illk } \\
\text { çiçeklenme }\end{array}$} & \multirow[t]{2}{*}{$\begin{array}{c}\text { Tam } \\
\text { çiçeklenme }\end{array}$} & \multirow[t]{2}{*}{$\begin{array}{l}\text { Çiçeklenme } \\
\text { sonu }\end{array}$} & \multicolumn{2}{|c|}{ Hasat } & \multicolumn{2}{|c|}{$\begin{array}{c}\text { Çiçeklenme - hasat } \\
\text { gün sayısı }\end{array}$} & \multicolumn{2}{|c|}{$\begin{array}{l}\text { Sicaklık toplamı } \\
\quad\left({ }^{\circ} \mathrm{C}\right)\end{array}$} & \multirow[t]{2}{*}{$\begin{array}{l}\text { Yaprak döküm } \\
\text { tarihi }\end{array}$} \\
\hline & & & & Boz & Ben & Boz & Ben & Boz & Ben & \\
\hline Uzun & 7 Nisan & 11 Nisan & & 3 Ağustos & 27 Ağustos & 114 & 138 & 2304 & 3036 & \\
\hline Siirt & 13 Nisan & 18 Nisan & 23 Nisan & 13 Ağustos & 1 Ekim & 117 & 166 & 2288 & 3680 & 21 Kasım \\
\hline
\end{tabular}

Yaprak dökümü Uzun çeşidinde 27 Kasım 2018'de, Siirt çeşidinde ise 21 Kasım 2018 tarihinde gerçekleşmiştir (Çizelge 1). 
Gaziantep'te yapılan bir çalışmada 6 yıllık ortalama verilere göre Uzun çeşidinin tam çiçeklenmesinin 17 Nisan'da, Siirt çeşidinin ise 20 Nisan'da gerçekleştiği belirtilmiştir.

Yine aynı çalışmada bu çeşitlerin ben hasat tarihleri sırasıyla 11 Eylül ve 24 Eylül olarak bildirilmiştir. Yaprak döküm tarihleri ise Uzun çeşidinde 31 Ekim, Siirt çeşidinde 27 Ekim olarak tespit edilmiştir (Tahtacı ve ark., 2007). Yıllık iklimsel farklılıklardan dolayı söz konusu tarihler değişim gösterebilmektedir.

\section{Dökülen Çeltik Sayısı}

Uzun çeşidinin boz hasat döneminde çeltik dökülme oranlarında istatistiksel olarak önemli farklılık belirlenmiş olup, hasat sırasında en fazla çeltik dökülme oranı \%71.3 ile 5000 ppm hormon uygulanan ağaçlarda saptanmış bunu sırasıyla 1000 ppm (\%65.7) ve 3000 ppm (\%61.2) takip emiş en az çeltik dökülme oranı ise \%49.3 ile hormon uygulanmayan kontrol grubunda görülmüştür (Çizelge 2).

Siirt çeşidinin boz hasat döneminde çeltik dökülme oranlarında istatistiksel olarak önemli farklılık belirlenmiş olup, en fazla dökülme oranı \%42.6 ile 3000 ppm hormon uygulanan ağaçlarda, en az çeltik dökülme oranı ise \%16 ile hormon uygulanmayan kontrol grubunda görülmüştür (Çizelge 2).

Çizelge 2. Uzun ve Siirt çeşitlerinin boz hasat döneminde hasat zamanı dökülen ve ağaçta kalan çeltik sayıları

\begin{tabular}{clcccc} 
Çeşitler & $\begin{array}{c}\text { Uygulanan } \\
\text { hormon } \\
\text { dozları }\end{array}$ & $\begin{array}{c}\text { Toplam Çeltik } \\
\text { Sayısı }\end{array}$ & $\begin{array}{c}\text { Dökülen Çeltik } \\
\text { Sayısı }\end{array}$ & $\begin{array}{c}\text { Ağaçta Kalan } \\
\text { Çeltik Sayısı }\end{array}$ & $\begin{array}{c}\text { Çeltik dökülme } \\
\text { oranları (\%) }\end{array}$ \\
\hline \multirow{2}{*}{ Uzun } & 1000 & 502 & 311 & 191 & $65.7^{\mathrm{a}}$ \\
& 3000 & 422 & 269 & 153 & $61.2^{\mathrm{a}}$ \\
& 5000 & 280 & 193 & 86 & $71.3^{\mathrm{a}}$ \\
LSD (\%5) & Kontrol & 725 & 358 & 367 & $49.3^{\mathrm{b}}$ \\
\hline \multirow{2}{*}{ Siirt } & 1000 & & & & 390.43 \\
& 5000 & 491 & 101 & 105 & $19.6^{\mathrm{bc}}$ \\
LSD (\%5) & Kontrol & 191 & 86 & 165 & $42.6^{\mathrm{a}}$ \\
\hline
\end{tabular}

Uzun çeşidinin ben hasat döneminde hasat sırasında en fazla çeltik dökülme oranı \%53.3 ile 5000 ppm hormon uygulanan ağaçlarda, en az çeltik dökülme oranı ise \%20 ile hormon uygulanmayan kontrol grubunda görülmüştür.

Hasattan beş ay sonra yapılan sayımda, hormon dozlarının çeltik dökülmesi üzerine etkisi istatistiksel olarak önemli olmasa da ağaçta kalan çeltiklerin dökülme oranı Uzun çeşidinde en fazla $\% 94.1$ oranı ile 5000 ppm hormon dozunda, en az ise 91.6 ile hormon uygulanmayan gruptaki ağaçlarda görülmüştür (Çizelge 3).

Siirt çeşidinin ben hasat döneminde, hormon dozlarının çeltik dökülmesi üzerine etkisi istatistiksel olarak önemli olmasa da en fazla çeltik dökülme oranı \%6.2 ile 5000 ppm hormon uygulanan ağaçlarda, en az çeltik dökülme ise \%2.5 ile hormon uygulanmayan kontrol grubunda görülmüştür (Çizelge 3).

Hasattan beş ay sonra yapılan sayımda, hormon dozlarının çeltik dökülmesi üzerine etkisi istatistiksel olarak önemli olmasa da ağaçta kalan çeltiklerin dökülme oranı en fazla \%92.7 oranı ile 5000 ppm dozunda, en az ise \%89.2 oranı ile kontrol grubunda görülmüştür (Çizelge 3).

Uygulanan ethephon hormonunun çeltiklerin dalla bağlantı noktasında kopma yüzeyi oluşturması hormon dozları ile doğru orantılı olarak artmıştır. Hasattan sonra ağaç üzerinde kalan bu çeltikler ocak ayına kadar gözlemlenmiş ve yine hormon dozu arttıkça dökülme oranlarının arttığı tespit edilmiştir. Daha önce bu konuda çalışma yapılmadığından bu veriler antepfıstığı için bir ilktir. 
Çizelge 3. Uzun ve Siirt çeşitlerinin ben hasat döneminde hasat zamanı dökülen ve ağaçta kalan çeltik sayıları ile sonraki dökülme oranları

\begin{tabular}{|c|c|c|c|c|c|c|c|}
\hline \multirow[b]{2}{*}{ Çeşitler } & \multirow{2}{*}{$\begin{array}{c}\text { Uygulanan } \\
\text { hormon } \\
\text { dozları }\end{array}$} & \multicolumn{3}{|c|}{ Hasat zamanı } & \multirow[b]{2}{*}{$\begin{array}{l}\text { Çeltik dökülme } \\
\text { oranları (\%) }\end{array}$} & \multicolumn{2}{|c|}{ Hasattan sonra } \\
\hline & & $\begin{array}{c}\text { Toplam Çeltik } \\
\text { Sayısı }\end{array}$ & $\begin{array}{c}\text { Dökülen } \\
\text { Çeltik Sayısı }\end{array}$ & $\begin{array}{c}\text { Ağaçta Kalan } \\
\text { Çeltik Sayısı }\end{array}$ & & $\begin{array}{c}\text { Ocak ayı } \\
\text { sayımı }\end{array}$ & $\begin{array}{l}\text { Dökülme } \\
\text { oranı (\%) }\end{array}$ \\
\hline \multirow{4}{*}{ Uzun } & 1000 & 245 & 67 & 177 & $28.3^{\mathrm{bc}}$ & 14 & 92.1 \\
\hline & 3000 & 229 & 108 & 121 & $45.0^{\mathrm{ab}}$ & 8 & 93.4 \\
\hline & 5000 & 369 & 183 & 185 & $53.3^{\mathrm{a}}$ & 11 & 94.1 \\
\hline & Kontrol & 566 & 113 & 452 & $20.0 \mathrm{c}$ & 38 & 91.6 \\
\hline $\operatorname{LSD}(\% 5)$ & & & & & 19.68 & & \\
\hline \multirow{3}{*}{ Siirt } & 1000 & 180 & 7 & 173 & 4.1 & 10 & 89.6 \\
\hline & 3000 & 133 & 5 & 128 & 4.0 & 11 & 91.4 \\
\hline & 5000 & 146 & 9 & 137 & 6.2 & 10 & 92.7 \\
\hline $\operatorname{LSD}(\% 5)$ & Kontrol & 198 & 5 & 194 & $\begin{array}{l}2.5 \\
\text { Ö.D. }\end{array}$ & 21 & 89.2 \\
\hline
\end{tabular}

\section{Hasat Başarısı/Etkinlik (\%) ve Hasat Süresi (sn.)}

Uzun çeşidinde boz hasat döneminde en yüksek hasat etkinliği \%83.1 ile 1000 ppm hormon dozunda görülürken, en az \%51.6 ile hormon uygulanmayan kontrol grubunda ölçülmüştür (Çizelge 4).

Çizelge 4. Uzun çeşidinin boz ve ben hasat dönemlerinde hasat edilen ürün miktarı, hasat etkinliği, taç hacmi ve hasat süreleri

\begin{tabular}{|c|c|c|c|c|c|c|}
\hline Dönem & $\begin{array}{l}\text { Uygulanan } \\
\text { hormon dozları } \\
\text { (ppm) }\end{array}$ & $\begin{array}{c}\text { Toplam hasat } \\
\text { edilen ürün } \\
(\mathrm{kg})\end{array}$ & $\begin{array}{c}\text { Hasat } \\
\text { edilen ürün } \\
(\mathrm{kg})\end{array}$ & $\begin{array}{c}\text { Ağaçta kalan } \\
\text { ürün } \\
(\mathrm{kg}) \\
\end{array}$ & $\begin{array}{c}\text { Hasat yüzdesi/ } \\
\text { etkinliği } \\
(\%)\end{array}$ & $\begin{array}{c}\text { Hasat Süresi } \\
\left(\text { sn. m3 ağaç } \text { act }^{-1}\right)\end{array}$ \\
\hline \multirow{5}{*}{ 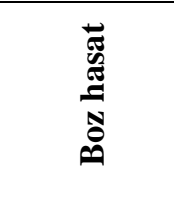 } & 1000 & 41.39 & 34.45 & 6.94 & $83.1^{\mathrm{a}}$ & $5.07^{\mathrm{b}}$ \\
\hline & 3000 & 42.46 & 33.12 & 9.34 & $76.9^{\mathrm{a}}$ & $4.57 \mathrm{bc}$ \\
\hline & 5000 & 25.67 & 18.67 & 7.00 & $77.0^{\mathrm{a}}$ & $1.44^{\mathrm{c}}$ \\
\hline & Kontrol & 33.35 & 17.20 & 16.15 & $51.6^{\mathrm{b}}$ & $2.76^{b c}$ \\
\hline & Elle hasat & 49.10 & 49.10 & 0.00 & & $37^{\mathrm{a}}$ \\
\hline $\operatorname{LSD}(\% 5)$ & & & & & 14.32 & 3.23 \\
\hline \multirow{5}{*}{ 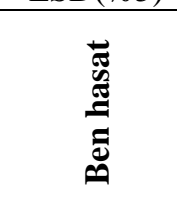 } & 1000 & 20.20 & 19.42 & 0.78 & $96.2^{\mathrm{b}}$ & $1.36^{\mathrm{b}}$ \\
\hline & 3000 & 23.00 & 22.65 & 0.36 & $98.1^{\mathrm{a}}$ & $2.63^{\mathrm{b}}$ \\
\hline & 5000 & 34.28 & 34.13 & 0.14 & $99.5^{\mathrm{a}}$ & $6.56^{\mathrm{b}}$ \\
\hline & Kontrol & 52.60 & 51.85 & 0.75 & $98.6^{\mathrm{a}}$ & $2.02^{b}$ \\
\hline & Elle hasat & 22.30 & 22.30 & 0.00 & & $16.0^{\mathrm{a}}$ \\
\hline $\operatorname{LSD}(\% 5)$ & & & & & 1.65 & 6.80 \\
\hline
\end{tabular}

Boz hasat döneminde hasat süresi incelendiğinde istatistiksel olarak fark önemli bulunmuş, elle hasat uygulamasının makinalı hasada göre uzun sürdüğü, ayrıca uygulanan farklı hormon dozları arasında da 5000 ppm hormon dozunun en kisa sürede hasat etmeye olanak sağladığı belirlenmiştir.

Ben hasat döneminde ise en yüksek hasat etkinliği \%99.5 ile 5000 ppm dozunda görülürken, en düşük \%96.2 ile 1000 ppm hormon dozu uygulanan ağaçlarda tespit edilmiştir (Çizelge 4).

Ben hasat döneminde hasat süresi incelendiğinde istatistiksel olarak fark önemli bulunmuş, elle hasat uygulamasının süresi makinalı hasada göre daha uzun olmuştur.

Uzun çeşidinde el ile hasat ve makinalı hasadın karşılaştırılması Çizelge 5'te görülmektedir. Boz hasat döneminde bir kişinin bir ağacı el ile 33.1 dakika hasat etmiş, aynı büyüklükteki ağacı makine ile 3.9 dakikada hasat etmiştir. Birim taç hacmi yönünden baktığımızda ise $1 \mathrm{~m}^{3}$ taç hacminin hasadı el ile 0.62 dakikada, makine ile 0.05 dakikada yapılmıştır.

Ben hasat döneminde ise bir işçi el ile saatte 3.7 ağacı hasat etmiş, makine ile de saatte 24 ağacı hasat etmiştir (Çizelge 5).

Ben hasat dönemindeki hasadın hem el hem de makine ile boz hasat dönemine göre daha hızlı olmasının sebebi salkımlarım dalla bağlantı noktasının boz hasat döneminde daha kuvvetli olması ile 
açıklanabilecektir. Atlı ve ark. (1999)'da çalışmalarında bizim çalışmamıza benzer şekilde ben hasat döneminde meyvelerin ve salkımların kolay koptuğunu belirtmişlerdir.

Çizelge 5. Uzun çeşidinde farklı hasat dönemlerinde el ile ve makine ile hasat uygulamalarının karşılaştırılması

\begin{tabular}{clcccc}
\hline Hasat dönemi & Hasat metodu & Ăgaç saat & & Hasat oranı \\
Dakika ağaç $^{-1}$ & Dakika kg $^{-1}$ & Dakika m $^{3}$ ağaç $^{-1}$ \\
\hline \multirow{2}{*}{ Boz } & El & 1.8 & 0.67 & 33.1 & 0.62 \\
& Makine & 15.4 & 0.11 & 3.9 & 0.05 \\
\hline \multirow{2}{*}{ Ben } & El & 3.7 & 0.74 & 16.4 & 0.27 \\
& Makine & 24.0 & 0.08 & 2.5 & 0.03 \\
\hline
\end{tabular}

Siirt çeşidinde boz hasat döneminde en yüksek hasat etkinliği \%96.4 ile kontrolde görülürken, en düşük oran \%91.4 ile 1000 ppm hormon uygulanan grupta belirlenmiştir (Çizelge 6).

Boz hasat döneminde ağaçların hasat süresi incelendiğinde istatistiksel olarak fark önemli bulunmuş, elle hasat süresinin makinalı hasada göre daha uzun olduğu, ayrıca uygulanan farklı hormon dozlarına göre hormon uygulanmayan kontrol grubunun en kısa sürede hasat edildiği belirlenmiştir.

Ben hasat döneminde ise bütün uygulamalarda ağaçtaki meyvelerin tamamı dökülmüştür. Dolayısıyla hasat etkinliği tüm uygulamalarda \%100 oranı ile eşit olduğu saptanmıştır. Polat ve ark. (2007) ben hasat döneminde; Siirt antepfıstığı çeşidinin hasat etkinliğini \%95.43, Kırmızı çeşidinin ise \%94.69 olarak hesaplamışlardır. Bu sonuçların bizim sonuçlarımızdan daha düşük olması hasadın anı zamanda yapılmasındandır.

Çizelge 6. Siirt çeşidinin boz ve ben hasat dönemlerinde hasat edilen ürün miktarı, hasat etkinliği, taç hacmi ve hasat süreleri

\begin{tabular}{|c|c|c|c|c|c|c|}
\hline $\begin{array}{l}\text { Hasat } \\
\text { dönemleri }\end{array}$ & $\begin{array}{l}\text { Uygulanan } \\
\text { hormon } \\
\text { dozları (ppm) }\end{array}$ & $\begin{array}{c}\text { Toplam hasat } \\
\text { edilen } \\
\text { ürün }(\mathrm{kg})\end{array}$ & $\begin{array}{l}\text { Hasat edilen } \\
\text { ürün (kg) }\end{array}$ & $\begin{array}{l}\text { Ağaçta kalan } \\
\text { ürün }(\mathrm{kg})\end{array}$ & $\begin{array}{l}\text { Hasat yüzdesi/ } \\
\text { etkinliği (\%) }\end{array}$ & $\begin{array}{l}\text { Hasat Süresi } \\
\left(\text { sn } \mathbf{m} 3 \text { ağaç }^{-1}\right)\end{array}$ \\
\hline \multirow{5}{*}{ Boz hasat } & 1000 & 41.77 & 38.22 & 3.56 & $91.4^{b}$ & $3.32^{b}$ \\
\hline & 3000 & 16.27 & 15.05 & 1.22 & $92.8^{b}$ & $1.88^{\mathrm{bc}}$ \\
\hline & 5000 & 21.22 & 19.82 & 1.40 & $93.6^{b}$ & $3.06^{b c}$ \\
\hline & Kontrol & 13.80 & 13.30 & 0.50 & $96.4^{\mathrm{a}}$ & $1.26^{\mathrm{c}}$ \\
\hline & Elle hasat & 31.25 & 31.25 & 0.00 & & $26.0^{\mathrm{a}}$ \\
\hline \multirow[t]{3}{*}{ LSD $(\% 5)$} & & & & & 2.29 & 2.01 \\
\hline & 1000 & 15.23 & 15.23 & 0.00 & 100.0 & $3.32^{b}$ \\
\hline & 3000 & 11.25 & 11.25 & 0.00 & 100.0 & $1.87^{b c}$ \\
\hline \multirow[t]{3}{*}{ Ben hasat } & 5000 & 12.43 & 12.43 & 0.00 & 100.0 & $3.05^{b c}$ \\
\hline & Kontrol & 16.65 & 16.65 & 0.00 & 100.0 & $1.26^{\mathrm{c}}$ \\
\hline & Elle hasat & 31.25 & 31.25 & 0.00 & & $27.93^{\mathrm{a}}$ \\
\hline LSD (\%5) & & & & & & 1.83 \\
\hline
\end{tabular}

Ben hasat döneminde ağaçların hasat süresi incelendiğinde istatistiksel olarak fark önemli bulunmuş, elle hasat uygulamasının makinalı hasada göre uzun sürdüğü, ayrıca uygulanan farklı hormon dozlarına göre hormon uygulanmayan kontrol grubunun en kısa sürede hasat edildiği belirlenmiştir (Çizelge 6).

Siirt çeşidinde boz hasat döneminde bir kişinin bir ağacı el ile 19.5 dakikada, aynı büyüklükteki ağacı makine ile 2.1 dakikada hasat ettiği belirlenmiştir. Birim taç hacmi yönünden baktığımızda ise 1 $\mathrm{m}^{3}$ taç hacminin hasadı el ile 0.37 dakikada, makine ile 0.04 dakikada yapılmıştır.

Ben hasat döneminde ise bir işçi el ile saatte 3 ağacı, makine ile de saatte 17.6 ağacı hasat etmiştir (Çizelge 7). Atlı ve ark. (1999) yaptıkları çalışmada bir dekar antepfıstığı bahçesini (16 ağaç) makine (dal sarsıcısı) ile 3 işçi kullanarak 1.5 saatte hasat etmişlerdir. Elle hasatta ise 3 işçi ile 16 ağacı 2.7 saatte hasat etmişlerdir. Bu çalışmada hasat süreleri bizim çalışmamıza göre oldukça uzun olmuştur. Bunun sebebi de sarsıcıları güçlerinin farklı olmasıdır. 
Her iki antepfıstığı çeşidinin boz ve ben hasat dönemlerinde hasat süresinin tespitine yönelik yapılan ölçümlerde ağaç taç hacimlerinin farklı olsa bile makinalı hasadın geleneksel (el ile) hasada göre daha hızlı olduğu belirlenmiştir.

Polat ve ark. (2007) yaptıkları bir çalışmada Kırmızı antepfıstı̆̆ı çeşidini el ve makine ile hasat ederek çıkan sonuçları karşılaştırmışlardır. Çalışmada bir işçinin bir ağacı makine ile 4.85 dakikada, elle 14.7 dakikada hasat edebildiğini belirtmişlerdir. Yaptığımız çalışmada elde edilen süreler arasında da benzer farklılık olduğu Çizelge 7'de görülmektedir.

\begin{tabular}{clcccc}
\multicolumn{2}{c}{$\begin{array}{c}\text { Cizelge 7. } \\
\begin{array}{c}\text { Hasat } \\
\text { dönemi }\end{array}\end{array}$} & $\begin{array}{l}\text { Hasat } \\
\text { metodu }\end{array}$ & Ağaç saat ${ }^{-1}$ & Dakika kg-1 & Hasat oranı \\
& & 3.1 & 0.40 & 19.5 & 0.37 \\
\multirow{2}{*}{ Boz } & El & 28.6 & 0.09 & 2.1 & 0.04 \\
& Makine & 3.0 & 0.89 & 20.0 & 0.33 \\
\multirow{2}{*}{ Ben } & El & 17.6 & 0.24 & 3.4 & 0.06 \\
& Makine & & & \\
\hline
\end{tabular}

\section{Meyve Kopma Kuvveti (kgF)}

Uzun çeşidinde boz hasat döneminde yapılan ölçümlerde çeltikten kopma kuvveti bakımından uygulamalar arasında istatistiksel olarak önemli farklılıklar belirlenmiş, en düşük 5000 ppm hormon dozu uygulanan ağaçlarda $0.91 \mathrm{kgF}$ olarak ölçülürken, en yüksek kontrol grubunda $1.30 \mathrm{kgF}$ olarak ölçülmüştür. İstatistiksel olarak tüm uygulamalar farklı bulunmuştur (Çizelge 8).

Uzun çeşidinde ben hasat döneminde ise yapılan ölçümlerde çeltikten kopma kuvveti bakımından uygulamalar arasında istatistiksel olarak önemli farklılıklar belirlenmiş, en düşük 5000 ppm hormon dozu uygulanan ağaçlarda $0.22 \mathrm{kgF}$ olarak ölçülürken, en yüksek kontrol grubunda $0.36 \mathrm{kgF}$ olarak ölçülmüştür. Daha önce bu konuda çalışma yapılmadığından bu veriler antepfıstığ için bir ilktir.

Çizelge 8. Uzun antepfıstığ 1 çeşidinin boz ve ben hasat dönemlerinde uygulanan farklı hormon dozlarında ölçülen kopma kuvvetleri $(\mathrm{kgF})$

\begin{tabular}{|c|c|c|c|c|c|c|c|c|}
\hline \multirow{2}{*}{$\begin{array}{l}\text { Hasat dönemi } \\
\text { Hormon dozları (ppm) }\end{array}$} & \multicolumn{4}{|c|}{ Boz } & \multicolumn{4}{|c|}{ Ben } \\
\hline & 1000 & 3000 & 5000 & Kontrol & 1000 & 3000 & 5000 & Kontrol \\
\hline Meyve Kopma Kuvveti (kgF) & $1.19^{\mathrm{b}}$ & $1.01^{\mathrm{c}}$ & $0.91^{\mathrm{d}}$ & $1.30^{\mathrm{a}}$ & $0.31^{\mathrm{b}}$ & $0.28^{\mathrm{b}}$ & $0.22^{\mathrm{c}}$ & $0.36^{\mathrm{a}}$ \\
\hline LSD $(\% 5)$ & \multicolumn{4}{|c|}{0.07} & \multicolumn{4}{|c|}{0.03} \\
\hline
\end{tabular}

Siirt çeşidinde boz hasat döneminde yapılan ölçümlerde çeltikten kopma kuvveti bakımından uygulamalar arasında istatistiksel olarak önemli farklılıklar belirlenmiş, en düşük 5000 ppm hormon dozu uygulanan ağaçlarda $1.10 \mathrm{kgF}$ olarak ölçülürken, en yüksek kontrol grubunda $1.82 \mathrm{kgF}$ olarak ölçülmüştür (Çizelge 9).

Siirt çeşidinde ben hasat döneminde ise yapılan ölçümlerde çeltikten kopma kuvveti bakımından uygulamalar arasında istatistiksel olarak önemli farklılıklar belirlenmiş, en düşük çeltikten kopma kuvveti 5000 ppm hormon dozu uygulanan ağaçlarda $0.19 \mathrm{kgF}$ olarak ölçülürken, en yüksek çeltikten kopma kuvveti kontrol grubunda $0.25 \mathrm{kgF}$ olarak ölçülmüştür (Çizelge 9).

Çizelge 9. Siirt antepfıstı̆̆ı çeşidinin boz ve ben hasat dönemlerinde uygulanan farklı hormon dozlarında ölçülen kopma kuvvetleri $(\mathrm{kgF})$

\begin{tabular}{|c|c|c|c|c|c|c|c|c|}
\hline \multirow{2}{*}{$\begin{array}{l}\text { Hasat dönemi } \\
\text { Hormon dozları (ppm) }\end{array}$} & \multicolumn{4}{|c|}{ Boz } & \multicolumn{4}{|c|}{ Ben } \\
\hline & 1000 & 3000 & 5000 & Kontrol & 1000 & 3000 & 5000 & Kontrol \\
\hline Meyve Kopma Kuvveti (kgF) & $1.52^{\mathrm{b}}$ & $1.29^{\mathrm{c}}$ & $1.10^{\mathrm{d}}$ & $1.82^{\mathrm{a}}$ & $0.23^{\mathrm{ab}}$ & $0.22^{\mathrm{b}}$ & $0.19^{c}$ & $0.25^{\mathrm{a}}$ \\
\hline $\operatorname{LSD}(\% 5)$ & \multicolumn{4}{|c|}{0.05} & \multicolumn{4}{|c|}{0.02} \\
\hline
\end{tabular}




\section{Meyvelerin Çeltikten Kopma Durumu}

Uzun çeşidinde boz hasat döneminde, salkımdan dökülen meyve oranları arasında istatistiksel olarak fark önemli olmuş, en yüksek döküm oranları \%66.3 ile 5000 ppm ve \%65.4 ile 3000 ppm hormon dozlarında gerçekleşmiştir.

Uzun çeşidinin ben hasat döneminde ise salkımdan dökülen meyve oranları arasında istatistiksel olarak fark önemli olmuş, en yüksek \%93.2 döküm oranı ile 5000 ppm ve 3000 ppm hormon dozunda (\%91.5) tespit edilmiştir (Çizelge 10).

Çizelge 10. Uzun antepfıstığı çeşidinde farklı hormon dozlarında salkımlardaki dökülen meyve sayıları ve oranları

\begin{tabular}{|c|c|c|c|c|c|c|}
\hline $\begin{array}{l}\text { Hasat } \\
\text { dönemleri }\end{array}$ & $\begin{array}{l}\text { Hormon dozları } \\
(\mathrm{ppm})\end{array}$ & $\begin{array}{l}\text { Kalan meyve } \\
\text { sayıs (adet) }\end{array}$ & $\begin{array}{c}\text { Dökülen meyve } \\
\text { sayısı (adet) }\end{array}$ & $\begin{array}{c}\text { Toplam meyve } \\
\text { sayıs1 (adet) }\end{array}$ & $\begin{array}{c}\text { Kalan meyve } \\
\text { oranı }(\%)\end{array}$ & $\begin{array}{c}\text { Dökülen meyve } \\
\text { oranı }(\%)\end{array}$ \\
\hline \multirow{4}{*}{$\begin{array}{l}\text { Boz hasat } \\
\text { dönemi }\end{array}$} & 1000 & 249 & 320 & 568 & 43.0 & $57.0^{\mathrm{b}}$ \\
\hline & 3000 & 159 & 302 & 461 & 34.6 & $65.4^{\mathrm{a}}$ \\
\hline & 5000 & 157 & 308 & 465 & 33.7 & $66.3^{\mathrm{a}}$ \\
\hline & Kontrol & 238 & 298 & 536 & 44.4 & $55.6 \mathrm{~b}$ \\
\hline LSD (\%5) & & & & & & 6.51 \\
\hline \multirow{4}{*}{$\begin{array}{l}\text { Ben hasat } \\
\text { dönemi }\end{array}$} & 1000 & 70 & 503 & 572 & 12.2 & $87.8^{b}$ \\
\hline & 3000 & 39 & 416 & 455 & 8.5 & $91.5^{\mathrm{a}}$ \\
\hline & 5000 & 36 & 506 & 543 & 6.8 & $93.2^{\mathrm{a}}$ \\
\hline & Kontrol & 74 & 439 & 513 & 14.4 & $85.6^{\mathrm{c}}$ \\
\hline LSD (\%5) & & & & & & 2.17 \\
\hline
\end{tabular}

Siirt çeşidinde boz hasat döneminde salkımdan dökülen meyve oranları arasında istatistiksel olarak fark önemli olmamıştır. En fazla döküm \%64 ile 5000 ppm hormon dozunda, en az döküm ise \%55.3 ile kontrol grubunda gerçekleşmiştir (Çizelge 11).

Çizelge 11. Siirt antepfıstı̆̆ı çeşidinde farklı hormon dozlarında salkımlardaki dökülen meyve sayıları ve oranları

\begin{tabular}{|c|c|c|c|c|c|c|}
\hline $\begin{array}{l}\text { Hasat } \\
\text { dönemleri }\end{array}$ & $\begin{array}{l}\text { Hormon dozlar } 1 \\
(\mathrm{ppm})\end{array}$ & $\begin{array}{l}\text { Kalan meyve } \\
\text { say1s1 (adet) }\end{array}$ & $\begin{array}{c}\text { Dökülen meyve } \\
\text { sayısı (adet) }\end{array}$ & $\begin{array}{l}\text { Toplam meyve } \\
\text { sayis1 (adet) }\end{array}$ & $\begin{array}{c}\text { Kalan meyve } \\
\text { oranı }(\%)\end{array}$ & $\begin{array}{c}\text { Dökülen meyve } \\
\text { oranı }(\%)\end{array}$ \\
\hline \multirow{4}{*}{$\begin{array}{l}\text { Boz hasat } \\
\text { dönemi }\end{array}$} & 1000 & 213 & 299 & 512 & 41.5 & 58.5 \\
\hline & 3000 & 169 & 290 & 459 & 36.9 & 63.1 \\
\hline & 5000 & 170 & 303 & 473 & 36.0 & 64.0 \\
\hline & Kontrol & 217 & 268 & 485 & 44.7 & 55.3 \\
\hline \multirow[t]{2}{*}{ LSD (\%5) } & & & & & & Ö.D. \\
\hline & 1000 & 69 & 554 & 623 & 11.3 & $88.7^{b}$ \\
\hline \multirow{3}{*}{$\begin{array}{l}\text { Ben hasat } \\
\text { dönemi }\end{array}$} & 3000 & 48 & 388 & 436 & 11.0 & $89.0^{\mathrm{b}}$ \\
\hline & 5000 & 34 & 428 & 463 & 7.4 & $92.6^{\mathrm{a}}$ \\
\hline & Kontrol & 61 & 427 & 488 & 12.5 & $87.5^{\mathrm{b}}$ \\
\hline LSD (\%5) & & & & & & 2.74 \\
\hline
\end{tabular}

Siirt çeşidinin ben hasat döneminde ise salkımdan dökülen meyve oranları arasında istatistiksel olarak fark önemli olmuş, en fazla döküm \%92.6 ile 5000 ppm hormon dozunda tespit edilmiştir. Kontrol, 1000 ppm ve 3000 ppm dozları aynı grupta yer almıştır (Çizelge 11).

Siirt ve Uzun çeşitlerinde hormon dozlarının artmasıyla salkımdan dökülen meyve sayısının arttı̆̆ görülmektedir. Daha önce bu konuda çalışma yapılmadığından bu veriler antepfıstığı için bir ilktir.

\section{Karagöz Sayımı}

Her iki çeşitte de uygulanan ethephon hormonunun karagöz dökülmesine bir etkisinin olmadığı, herhangi bir uygulama yapılmayan kontrol grubuyla benzer sonucun ortaya çıktığı görülmüştür. 


\section{Yaprak Dökümü}

Ben hasat döneminde ise Uzun çeşidinde en fazla yaprak dökümü kontrol grubunda, en az ise 1000 ppm dozunda olmuştur. İstatistiksel olarak 1000 ppm, 3000 ppm hormon dozları ile elle hasat arasında fark görülmezken, bu uygulamalar ve diğer uygulamalar arasında farklılık görülmüştür.

Siirt çeşidinin ben hasat döneminde istatistiksel olarak 5000 ppm ve kontrol aynı grupta yer alırken, diğer uygulamalar ile aralarında fark olduğu ortaya çıkmıştır. En az yaprak dökümü kontrol ve 5000 ppm dozunda, en fazla ise elle hasatta olmuştur.

\section{Pomolojik Özellikler}

Farklı hormon dozlarının Uzun çeşidi boz hasat döneminde meyvelerinin dış kabuk rengi ve randıman değerleri haricinde diğer kalite parametrelerine etkisinin olmadığı anlaşılmıştır.

Uzun çeşidi boz hasat döneminde alınan örneklerde uygulamalar arasında istatistiksel olarak farklılık görülmüştür. En yüksek randıman oranı 1000 ppm dozunda \% 43, en düşük ise herhangi bir uygulama yapılmayan kontrol grubunda \%38.1 ile tespit edilmiştir.

Uzun çeşidi boz hasat döneminde alınan örneklerde dış kabuk renklenmesine bakıldığında uygulamalar arasında önemli farklılıklar tespit edilmiştir. Dış kabuk renklenmesi en fazla \% 46.3 ile 5000 ppm dozunda olduğu, en düşük oranın ise \%10 ile kontrol grubunda olduğu tespit edilmiştir.

Uzun çeşidi ben hasat döneminde alınan örneklerde en yüksek çıtlama oranı \%61.7 ile 1000 ppm dozunda tespit edilirken, en düşük herhangi bir uygulama yapılmayan kontrol grubunda \%29 olarak saptanmıştır. Ben hasat döneminde çıtlama oranları ve randıman açısından istatistiksel olarak fark görülmemiştir. Atlı ve ark. (1999) Uzun çeşidinin ben hasat döneminde çıtlama oranını bizim sonuçlarımıza benzer olarak \%60 olarak belirlemişlerdir.

Uzun çeşidi ben hasat döneminde alınan örneklerde dış kabuk renklenmesine bakıldığında istatistiksel olarak uygulamalar arasında önemli farklılıklar belirlenememiştir. Bununla birlikte diş kabuk renklenmesi en fazla \%97.7 ile 3000 ppm dozunda olduğu belirlenmiş, en düşük oranın \% 75 ile kontrol grubunda olduğu tespit edilmiştir.

Siirt çeşidinin boz ve ben hasat döneminde alınan örneklerde randıman oranları bakımından istatistiksel olarak fark görülmemiştir.

Siirt çeşidinin boz hasat döneminde en yüksek çıtlama oran1 5000 ppm dozunda \%77, en düşük ise kontrol grubunda \%61 ile tespit edilmiştir. İstatistiksel olarak 5000 ppm ile 1000 ppm hormon dozu uygulamaları aynı grupta yer alırken, bu grup ile kontrol ve 3000 ppm hormon dozu uygulamaları arasında önemli farklılıklar belirlenmiştir.

Siirt çeşidinin boz hasat döneminde dış kabuk renklenmesine bakıldığında ise en yüksek değer \%80.7 ile 5000 ppm dozunda olduğu belirlenmiş olup en düşük oranın \%71.0 ile kontrol grubunda olmasına karşın istatistiksel olarak uygulamalar arasında herhangi bir fark ortaya çıkmamıştır.

Siirt çeşidinin ben hasat döneminde alınan örneklerden ise en yüksek çıtlama oranı \%98.0 ile 3000 ppm dozunda, en düşük ise \%83 olarak herhangi bir uygulama yapılmayan kontrol grubunda ölçülmüş, istatistiksel olarak 1000 ppm ve 3000 ppm hormon uygulamaları aynı grupta yer alırken, kontrol ve 5000 ppm hormon dozu uygulaması diğer grupta yer almıştır. Atlı ve ark. (1999) Siirt çeşidinin ben hasat döneminde çıtlama oranını bizim sonuçlarımıza benzer olarak \%98.6 olarak belirlemişlerdir.

Siirt çeşidinin ben hasat döneminde dış kabuk renklenmesine bakıldığında ise istatistiksel olarak fark bulunmuştur. En fazla dış kabuk renklenmesi \%96.3 ile 5000 ppm dozunda belirlenmiş olup en düşük oranın \%93.0 ile kontrol grubunda tespit edilmiştir. 
Tahtacı ve ark. (2007) yaptıkları çalışmada dört yılın ortalama verilerine göre Siirt çeşidinin kuru kırmızı kabuklu yüz dane ağırlığını $133.80 \mathrm{~g}$, çıtlama oranını \%88, randımanını \%42 olarak bulmuştur. Çalışmamızda ben hasat döneminde elde ettiğimiz verilerle karşılaştırdığımızda kuru kırmızı kabuklu yüz dane ağırlığı, randıman ve çıtlama oranları bakımından birbirine çok yakın değerler ortaya çıkmıştır.

Çalışmamızda kullanılan hormon dozlarının hem boz hem de ben hasat döneminde hasat edilen meyvelerin çıtlaması üzerine olumlu etkisinin olduğu görülmüştür.

\section{SONUÇ}

Çalışma sonucunda, makinalı hasadın antepfıstığı yetiştiriciliğinde önemli bir maliyet oluşturan geleneksel hasat yöntemine karşı özellikle süre açısından oldukça avantajlı olduğu anlaşılmıştır.

Uygulanan farklı hormon dozları ise antepfıstığı salkımlarının daldan düşmesine olumlu etki yapmıştır. Aynı zamanda antepfıstığı tanelerinin salkımdan kopmasını da kolaylaştırmıştır. Çıtlama oranlarına da olumlu etki yapan ethephon hormonu, meyve diş kabuğunun renklenmesini de artırmıştır.

$\mathrm{Bu}$ çalışma sonucunda elde edilen veriler ışı̆̆ında Türkiye koşullarına ve antepfıstığı yetiştiriciliğine uygun makinaların geliştirilmesi gerektiği ortaya çıkmıştır.

Antepfistığı hasadı amaca uygun olarak boz veya ben olum dönemleri iyi takip edilerek hasat edilmelidir. Boz hasadın erken yapılması iç meyvenin küçük kalmasına sebep vermekte, dolayısıyla ürün kaybı yaşanmaktadır. Geç yapılması ise ürünün yeşil iç renginin sarıya doğru dönmesine neden olarak pazar değerinin düşmesine sebep olabilmektedir. Ben hasadın erken yapılması çıtlama oranının düşmesine sebep olmakta, geciktirilmesi ise meyvenin yere dökülmesi nedeniyle fazladan işgücü gerektirmektedir. Geç hasat ayrıca kuş zararının artmasına da yol açabilmektedir.

Yeni kurulan ve kurulacak olan antepfıstığı bahçeleri mekanik hasada uygun olacak şekilde tesis edilmeli, ağaçlara mekanizasyona uygun şekil verilmelidir.

\section{KAYNAKLAR}

Anonim, 2018a. Dünya Antepfıstığı Üretimi, http://www.fao.org/faostat/en/\#data/QC (Erişim Tarihi: 01.10.2018).

Anonim, 2018b. Dünya Antepfıstı̆̆ İhracat1, http://www.fao.org/faostat/en/\#data/TP (Erişim Tarihi: 01.10.2018).

Arpacı S, Akkök F, Tekin H, 1995. Sulu ve Kuru Koşullarda Yetiştirilen Antepfıstıklarında Gelişme ve Verim Değerlerinin İncelenmesi. Türkiye II. Bahçe Bit. Kong. Cilt 1. S. 429-433. Adana.

Arpacı S, Atlı H S, Tekin H, 1999. Verim Çağındaki Antepfistıklarında Budama Tekniğinin Geliştirilmesi. Tarım ve Köyişleri Bakanlığı Tar. Araşt. Gn. Müd., Yayın No:11, S.31.

Atlı H S, Arpacı S, Akgün A, Özgüven A I, Özgüven F, 1999. Bazı Antepfıstı̆̆ Çeşitlerinin Hasat Zamanının Saptanması ve Makineli Hasadın Uygulanabilme Durumunun Araştırılması. Türkiye III. Ulusal Bahçe Bit. Kong. S.248 - 251. Ankara.

Atlı H S, Arpacı S, Akgün A, Uygur N, 2002. Standart Antepfıstığı Çeşitlerine Anaç Seçimi. Tarım ve Köyişleri Bakanlığı Tarımsal Araştırmalar Genel Müdürlüğü, Sonuç Raporu.

Atlı H S, Arpacı S, Açar İ, Kaşka N, Aydın Y, Bilgel L, Ak B E, Kafkas S, Bozkurt H, 2008. Farklı Anaçlar Üzerine Aşılı Antepfistığı Çeşitlerinin Sulu Koşullarda, Gelişme, Meyveye Yatma, Verim ve Bazı Kalite Değerlerinin Karşılaştırılması. Tarım ve Köyişleri Bakanlığı Tarımsal Araştırmalar Genel Müdürlüğü, Sonuç Raporu.

Ayfer M, 1959. Antepfıstığının Döllenme Biyolojisi Üzerinde Araştırmalar. Ankara Üniversitesi Ziraat Fakültesi Yayınları 148, Çalışmalar 93.104 s. 
Ayfer M, Köksal İ, Çelik M, Kaynak L, Gülşen Y, 1986. Meyvecilik Potansiyelinin Geliştirilmesi. Güneydoğu Anadolu Projesi Tarımsal Kalkınma Sempozyumu (Ayrı Basım) S. 189-210 Ankara.

Beyhan M A, Yıldız T, 1996. Findık ve Diğer Sert Kabuklu Meyvelerde Uygulanan Mekanik Hasat Yöntemleri. OMÜ Zir. Fak., Fındık ve Diğer Sert Kabuklu Meyveler Sempozyumu, Bildiri Kitabı, 185-194, 10-11 Ocak, Samsun.

Eldoğan Ü, Şahin A, 2015. Gaziantep İlinde Antepfıstığı Üretim Ekonomisi Araştırması. KSÜ Doğa Bil. Derg., 18(3), 2015.

Joley L E, 1973. (Çeviren Bilal Yardımcı). Sert Kabuklu Fıstık (Antepfıstığı). Tar. Bak. Zir. İşl. Gn. Md. Yayınları D-154. Ankara.

Özbek S, 1978. Özel Meyvecilik Kışın Yaprağını Döken Meyve Türleri. Ç.Ü. Ziraat Fak. Yayınları. No:128 S.322-364. Adana.

Pırlak L, Güleryüz M, 2000. Meyvelerin Mekanik Yolla Hasadı. Tarımsal Mekanizasyon 19. Ulusal Kongresi, Bildiri Kitab1, 253-258, 1-2 Haziran, Erzurum.

Polat R, Gezer İ, Güner M, Dursun E, Erdoğan D, Bilim H C, 2007. Mechanical Harvesting of Pistachio Nuts. Journal of Food Engineering, 79: 1131-1135.

Sergio Castro G, Blanco-Roldán G L, Gil-Ribes J A, Agüera-Vega J, 2008. Dynamic Analysis of Olive Trees in Intensive Orchards Under Forced Vibration. Trees, 22, 795-802.

Simmons S R, Oelke E A, Wiersma J V, Lueschen W E, Warnes D D, 1988. Spring Wheat and Barley Responses to Ethephon. Agronomy Journal 80:829-834.

Spiegel-Roy P, Mazigh D, Evenari M, 1977. Response of Pistachio to Low Soil Moisture Conditions. J. Amer. Soc. Hort. Sci. 102 (4), 470-473.

Tahtacı S, Arpacı S, Gözel H, Bilim C, Atlı H S, Tekin H, 2007. Antepfıstığında Çeşit Seçimi. Sonuç Raporu, Tarım ve Köyişleri Bakanlığı Tarımsal Araştırmalar Genel Müdürlüğü, Gaziantep, 2007.

Tekin H, 1991. Gaziantep Yöresinde Topraktan ve Yapraktan Yapılan Farklı Gübre Uygulamalarının Antepfıstığının Yaprak Bileşimi, Gelişme, Verim ve Ürün Kalitesine Etkilerinin Araştırılması. Sonuç Raporu, Antepfistığg Araştırma Enstitüsü, 72 s.

Tekin H, Arpacı S, Atlı H S, Karaca R, Mart C, Turan K, 1995. Antepfistığı Yetiştirme Tekniği. Antepfıstığı Araştırma Enstitüsü Müdürlüğü, Yayın No:4, 36 s. Gaziantep.

Tous J, Girona J, Tasias J, 1994. Cultural Practice Sand Costs in Hazelnut Production. III. International Congress On Hazelnut, Acta Hort., 351, 395-418, September 14-18 Alba, Italy.

Tuncer İ K, Özgüven F, 1989. Bağ Bahçe Sebze ve Endüstri Kültürlerinde Mekanizasyon Uygulamaları. Çukurova Üniversitesi Ziraat Fakültesi Ders Kitabı, No: 115 (Prof. Dr. Ing. E. Moser'den çeviri). Uzun M, 1998. Antepfistıklarında Buharlaştırarak Soğuklatma (Evaporative Cooling) Yöntemiyle Çiçeklenmenin Geciktirilmesi. Yüksek Lisans Tezi, KSÜ, 51s. Kahramanmaraş.

Yalçın M, Acıcan T, Alibaş K, Ertürk Ü, Soylu A, Akça Y, 2012. Ceviz (J. Regia L.) Meyvesinin Hasadında Kullanılan Farklı Yöntemlerin Karşılaştırılması. Bahçe, 41 (2): 13 - 21 (2012). 